\title{
«QUE.ALS DITS ORDENAMENTS E CAPÍTOLS SIEN MESES EN MEMÒRIA DE SCRIPTURA». MODELOS DE IDENTIDAD URBANA EN EL REINO DE VALENCIA, SIGLOS XIII-XV
}

\author{
Juan Antonio Barrio Barrio ${ }^{1,2}$ \\ Universidad de Alicante
}

\section{RESUMEN}

La conquista de la ciudad de Valencia en 1238 y la culminación de la ocupación del resto del reino en 1245 con la toma de Biar, ponían fin, a la fase militar de la campaña levantina del rey conquistador y daban paso a la etapa de la construcción política, institucional, territorial e identitaria de las tierras conquistadas para la Corona de Aragón e incorporadas a la cristiandad occidental, tras cerca de seis siglos bajo dominio islámico. Este proceso dirigido por la monarquía en colaboración con las elites urbanas del reino, se realizo de forma gradual y progresiva, fraguando en el Cuatrocientos unos modelos de identidad urbana incardinados en los principales centros urbanos del reino de Valencia. El objetivo de este artículo es analizar los principales elementos constitutivos de dichos modelos de identidad urbana en el reino de Valencia. Nos hemos centrado en los que consideramos los cimientos y pilares de los modelos de identidad urbana en el reino de Valencia, la codificación normativa, el espíritu religioso y cívico y la articulación político-institucional del reino.

Palabras clave: Identidad, municipio, Reino Valencia, siglos XIII, XIV y XV.

1 Doctor en Historia. Profesor Titular. Departamento de Historia Medieval, Historia Moderna y Ciencias y Técnicas Historiográficas. Universidad de Alicante. 03080. Alicante. C.e.: ja.barrio@ua.es.

2 La presente aportación ha sido elaborada en el marco del proyecto de investigación «Fundamentos de identidad política: la construcción de identidades políticas urbanas en la Península Ibérica en el tránsito a la modernidad» (HAR2009-08946) y «Redes de sociabilidad judeoconversa y actuación inquisitorial en la Corona de Aragón en el siglo XV» (HAR 2008-02650/HIST). 


\begin{abstract}
The conquest of the city of Valencia in 1238 and the culmination of the occupation of the rest of the kingdom in 1245, when Biar was taken, brought the military phase of the conquering king's eastern campaign to an end, ushering in a new stage to establish the politics, institutions, territory and identity of the conquered lands for the Crown of Aragón and their incorporation into western Christendom, after almost six centuries of Islamic rule. Led by the monarchy in collaboration with the kingdom's urban elite, this was a gradual and progressive process that saw the emergence of urban identity models in the $15^{\text {th }}$ century linked to the main urban populations of the kingdom of Valencia. The objective of this study is to analyse the main elements of these urban identity models in the kingdom of Valencia, focusing on the models' foundations and pillars, the development of a legal code, religious and civic spirit, and the kingdom's political and institutional co-ordination.
\end{abstract}

Keywords: Identity, municipality, Kingdom Valencia, $13^{\text {th }}, 14^{\text {th }}$ and $15^{\text {th }}$ centuries.

\title{
1. LA CODIFICACIÓN NORMATIVA: FUEROS, PRIVILEGIOS Y ORDENANZAS MUNICIPALES.
}

El municipio surgió en la Europa medieval de forma lenta y gradual, cuando los principales centros urbanos deseosos de obtener la independencia jurídica de reyes, obispos, nobles o del propio emperador, obtuvieron de sus soberanos a través de la fuerza o mediante negociación, la posibilidad de disponer de un órgano colegiado propio de gobierno, el consulado. Nació de esta forma y sobre todo en Italia la comuna y en los territorios del sur de Francia, el consulado. Estos movimientos comunales surgieron a finales del siglo XI y se extendieron durante el siglo XII. Es la génesis del municipio medieval europeo. La obtención por parte de las urbes de privilegios jurídico-políticos, de instituciones de autogobierno, franquicias, exenciones, privilegios, en definitiva de libertades cívicas, constituye un hito histórico ${ }^{3}$, esencial, para entender la historia urbana y ciudadana de Europa.

Cuando Jaime I conquista Valencia en 1238, el proceso de creación y desarrollo del municipio, así como la introducción del derecho romano se encuentran en un momento de plenitud y maduración ${ }^{4}$. De esta forma la constitución de los primeros municipios valencianos se hizo en paralelo a la difusión e introducción

\footnotetext{
MONSALVO, J.M. a , Las ciudades europeas del medievo. Madrid, 1997, pág. 144.

+ RIGAUDiERE, A., Gouverner la Ville au Moyen Age. París, 1993, págs. 16-17.
} 
de conceptos como la Universitas 5 y la Res Publica. Para Francesc Eiximenis «la res publica es una comunidad de gentes viviendo bajo una misma ley - en el sentido jurídico y religioso -, un mismo señorío y unas mismas costumbres» ${ }^{6}$.

Esta actuación de Jaime I hay que insertarla en el contexto de una acción conquistadora y de gobierno dirigida a una estabilización definitiva de los territorios heredados y conquistados ${ }^{7}$, frente a precedentes anteriores estériles y efímeros como el llevado a cabo por el Cid en tierras valencianas, o la aventura occitana de su padre, cuya prematura muerte en la batalla de Muret en 1213 pudo haber supuesto la desaparición de la Corona de Aragón.

Surgirá la necesidad de elaborar un marco identitario al servicio de los centros urbanos conquistados y colonizados o fundados por elites dirigentes cristianas, bajo unos parámetros que no coinciden, necesariamente, con la forja identitaria de los centros urbanos de las ciudades del centro y norte de Italia, paradigmas de la esencia identitaria urbana, del «vivere civico» ${ }^{8}$. En una parte de los centros urbanos de Italia, sobre todo los del centro y norte, la ausencia de un fuerte sistema estatal de matriz dinástico-patrimonial había permitido a las elites urbanas fundar su propia identidad urbana sobre el culto a la memoria de su ciudad y sobre el monopolio de los estatutos comunales $^{9}$. Identidad asociada con claridad a la ciudad desde sus orígenes ${ }^{10}$. El sentido patriótico estaba asociado a su ciudad natal, Florencia por ejemplo y no a Italia ${ }^{11}$.

5 BARRIO BARRIO, J.A., «La introducción del término Uniuersitas en las instituciones municipales del reino de Valencia», NASCIMIENTO, A.A., ALBERTO, P.A., IV Congreso Internacional de Latim Medieval Hispânico. Lisboa, 2006, págs. 191-201. MICHAUD-QUANTIN, P., Universitas. Expressions du mouvement communautaire dans le Moyen-Age Latin. París, 1970. RIBALTA HARO, J. TURULL RUBINAT, M. «De voluntate Universitatis. La formación y l'expressió de la voluntat del municipi ( Tàrrega, 1214-1520 )», Anuario de Estudios Medievales, n. ${ }^{\circ}$ 21, Barcelona, 1991, pág. 159.

6 MARTíN, J.L., La ciudad y el príncipe. Barcelona, 2004, pág. 75.

7 BELENGUER, E., Jaime I y su reinado. Lleida, 2008, pág. 115. La emisión de la serie El Camino del Cid por Televisión Española en el año de conmemoración del nacimiento de Jaime I ilustra sobre esta diferente óptica en el tratamiento dado al Cid y a Jaime I por parte de determinadas instituciones públicas.

8 CHITTOLINI, G., «Inroduzione: una traccia per i lavori», CHITTOLNI, G., JOHANEK, P., (Eds.), Aspetti e componenti dell 'identità urbana in Italia e in Germania (secoli XIV-XVI), Bologna, 2003, págs. 7-8.

9 FORLIN, M., «Principi e città in Italia fra medioevo ed età moderna: nota a margine del caso ferrarese», CHITTOLNI, G., JOHANEK, P., (Eds.), Aspetti e componenti dell'identità urbana..., pág. 42.

${ }^{10}$ DE MATTEIS, M.C., «Societas christiana e funzionalità ideologica della città in Italia: linee di uno svilupo», ELZE, R., FASOLI, G., (Eds.), Le città in Italia e in Germanoia nel Medioevo: cultura, istituzioni, vita religiosa. Bologna, 1981, pág. 15.

${ }^{11}$ HANKEY, T., «Civic Pride versus Feelings for Italia in the Age of Dante», SMYTH, A., (Ed.), Medieval Europeans. Studies in Etnic Identity and National Perspectives in Medieval Europe. New York, 1998, pág. 200. 
Frente a este modelo propio de las ciudades del norte y centro de Italia y que la historiografía ha potenciado, como paradigma del desarrollo identitario urbano, Pietro Corrao ha puesto de manifiesto la importancia que tuvo en el sur de Italia el modelo urbano de la Universitas y las ventajas que para los centros urbanos suponía incorporarse al espacio público de la monarquía catalano-aragonesa, a su red urbana y a los circuitos de poder y de influencia del ámbito de la Corona de Aragón ${ }^{12}$ y considera la codificación normativa de los privilegios, leyes y costumbres de una ciudad, uno de los elementos más importantes de la identidad ciudadana $^{13}$. Para Corrao, en Sicilia esta autonomía política se fundamentaba, en la costumbre, los privilegios, la fiscalidad local e instituciones electivas, que formaban el núcleo de la identidad ciudadana, que permitía ejercer un control sobre el territorio, frente a las aristocracias feudales ${ }^{14}$. Las ciudades del reino de Valencia, en situaciones en las que veían comprometida su autonomía política, apelaban a la conservación de los privilegios, libertades, usos y buenas costumbres de la ciudad $^{15}$. En las ciudades de la Europa occidental los «bonos usus et consuetudines», formaban parte al ordenamiento que se aplicaba en cada centro urbano y remitía a lo que era más antiguo ${ }^{16}$.

Cauchies ha situado en el origen de la práctica legislativa en los centros urbanos, la necesidad de afirmar una identidad, sobre todo a partir de la capacidad de los municipios de establecer normativas propias, ordenanzas municipales, que van a ser el reflejo de una voluntad, de una identidad ${ }^{17}$. Las ordenanzas municipales son la base de la autonomía municipal, de ahí el inusitado interés en conservarlas en los archivos locales ${ }^{18}$ y eran la máxima expresión de la legislación de la ciudad, siendo el principal elemento constitutivo del derecho

${ }^{12}$ CORRAO, P., «La difficile identità della città siciliane», CHITTOLINI, G., JOHANEK, P., (Edit.), Aspetti e componenti dell identità urbana..., pág. 105.

${ }^{13}$ Ibídem, pág. 108.

${ }^{14}$ Ibídem, pág. 102.

${ }^{15}$ En las ciudades del reino de Valencia, esta apelación a los buenos usos y las costumbres de la ciudad, se realizaba sobre todo ante injerencias de los oficiales reales o de la propia monarquía. Vid. BARRIO BARRIO, J.A., CABEZUELO PLIEGO, J.V., «La defensa de los privilegios locales y la resistencia a la centralización política en la gobernación de Orihuela», Anales de la Universidad de Alicante. Historia Medieval, 13 (2003), 9-42.

${ }^{16}$ AMMANN-DOUBLIEZ, CH., «Le grand livre des ordonnances de Fribourg / Suisse (13631466): Genèse et fonctions». CAUCHIES, J-M. BOUSMAR, E., (Dir.), "faire bans, edictz et status»: légiférer dans la villa médiévale. Bruxelles, 2001, pág. 24 y ss.

${ }^{17}$ CAUCHIES, J-M., «L'activité législative communale dans l'occident médiéval: directions et pistes de recherche», CAUCHIES, J-M. BOUSMAR, E., (Dir.), «faire bans, edictz et status»... pág. 2.

${ }^{18}$ CHITtOlini, G., «Legislazione statutaria e autonomie nella pianura bergamesca», Città, comunità e feudi negli stati dell'Italia centro-settentrionale (secoli XIV-XVI), Milano, 2000, pág. 107. 
urbano $^{19}$. Goddin ha recalcado, en este sentido, la intensa actividad legislativa que se dio en los centros urbanos durante los siglos XIII y XIV, superior cuantitativamente a lo legislado por el Emperador, los reyes y los señores ${ }^{20}$

El impacto del valor político, legal y el sustento de la memoria histórica ${ }^{21}$ de la ciudad y sus linajes, realizados a través de las ordenanzas locales, constituyen algunos de los argumentos que explican la necesidad de la registración ${ }^{22}$ de la producción ordenancista ${ }^{23}$ de los municipios del reino de Valencia. Al mismo tiempo, se defenderán las peculiaridades históricas de los centros urbanos constituidos sobre medinas islámicas que habían tenido ricas huertas asociadas a la urbe, recordando su herencia islámica a partir de un legado que se va mantener $^{24}$, sobre todo en lo referente a la tecnología hidráulica, a la organización jurídica del regadío y a la organización de los primeros alfoces ${ }^{25}$.

Por el contrario, en el caso de las bastidas o villas de nueva fundación, contamos con el ejemplo de la villa de Guardamar, que fue creada en fecha imprecisa por Alfonso X en una gran pinada que no había sido nunca urbanizada ni poblada por musulmanes. El rey castellano construyó un castillo y en la zona baja, en una gran pinada, se edifico la villa que bautizó como Guardamar que debía ser

${ }^{19}$ CHITTOLINI, G., «La validità degli statuti cittadini nel territorio (Lombardia, sec. XIV-XV», CAUCHIES, J-M. BOUSMAR, E., (Dir.), «faire bans, edictz et status»... pág. 263.

${ }^{20}$ GODDING, P., «Les ordonnances des autorités urbaines au Moyen Âge : leur apport à la technique législative», DUVOSQUEL, J-M. THOEN, E., (Eds)., Peasants and townsmen in Medieval Europe: studia in honorem Adriaan Verhulst. Leuven, 1995, pág. 185.

${ }^{21}$ Para un excelente análisis teórico del papel de la memoria histórica vid. SESMA MUÑOZ, J.A., «La creación de la memoria histórica. Una selección interesada del pasado», DE LA IGLESIA DUARTE, J.A., MARTÍN RODRÍGUEZ, J.L., (Coord.), Memoria, rito y realidad en la historia medieval. XII Semana de Estudios Medievales, Nájera, del 29 de julio al 2 de agosto de 2002, Logroño, 2003, págs. 13-32. El resto de aportaciones del presente volumen, resultan también de gran interés para el estudio de la memoria histórica y el papel del mito en la elaboración del discurso histórico.

${ }^{22}$ Para el análisis de la registración documental en la Edad Media vid. CLANCHY, M.T., From Memory to Wrintten Record. England 1066-1307. Oxford (UK) \& Cambridge (USA), 2001.

${ }^{23}$ CAUCHIES, J-M., «L'activité législative communale dans l’occident médiéval... págs 5 y ss.

${ }^{24}$ Va a aparecer una expresión característica en la documentación para aludir a esta situación. «Como en tiempo de moros», va a indicar en diferentes cuestiones referidas a la organización del riego, las veredas, etc., que se mantenía igual que en la época de dominación musulmana. La expresión «el tiempo de los moros», equivalía también a reconocer la validez sobre determinados derechos sobre el agua. GLICK, TH.F., Paisajes de conquista. Cambio cultural y geográfico en la España medieval. Valencia, 2007, pág. 177.

${ }^{25}$ La villa de Orihuela fue dotada en 1266 de su término con los lugares de Abanilla, Crevillente, Albatera, Cox, Arrabal y Almodovar, recuperando el término que había tenido la Medina de Orihuela en época Almohade «assi como los ouieron en tiempo de moros». TORRES FONTES, J.A., Fueros y privilegios de Alfonso X el Sabio al Reino de Murcia. Murcia, 1973, doc. nº. LXXIII, ( 1266, julio, 15), págs. 89-91. 
poblada por los propietarios de las tierras de los alrededores ${ }^{26}$. Esta descripción forma parte de un relato «fundacional», incluido en una carta enviada a Jaime II en 1304, treinta y tres años después de la recepción del Fuero, por lo que es factible que todavía siguiesen vivos algunos de los primeros colonos que ocuparon la nueva villa de Guardamar y por tanto, los fundadores del centro urbano. Hacían constar, además expresamente y con orgullo patriótico que en ese lugar nunca habían vivido los «moros» y se enfatizaba el papel defensivo del castillo para proteger a los pobladores de la nueva villa.

Otra situación se produjo en los municipios que fueron incorporados al reino de Valencia tras la Sentencia Arbitral de Torrellas de 1304, tras la conquista del reino de Murcia realizada en 1296 por Jaime II, que había concedido nuevos y beneficiosos privilegios a villas como Orihuela y Alicante. En 1296 el recién instaurado discurso político tras la ocupación castellana del reino Murcia, quedaba de inmediato arrumbado en la memoria histórica, y la nueva cúpula dirigente urbana territorial se debía aprestar en la elaboración de un nuevo discurso político, acorde con la nueva era histórica que se iniciaba y la correspondiente memoria histórica, ajustada a las directrices de la pertenencia a la Corona de Aragón desde 1296 y al reino de Valencia desde 1304 y al papel providencial de los linajes dirigentes en sus acciones, militares y de gobierno.

Al mismo tiempo las autoridades locales de villas como Orihuela, se esforzaban por preservar los privilegios más beneficiosos recibidos en la época de dominación castellana y los decisivos que recibió de Jaime II en la etapa en que Orihuela permaneció en el reino de Murcia ${ }^{27}$.

En el reino de Valencia el nacimiento de las instituciones municipales fue inmediato ${ }^{28}$, con un desarrollo rápido pero escalonado de la articulación

${ }^{26}$ FERRER I MALLOL, M. ${ }^{a}$ T. Organització i defensa d’un territori fronterer. La Governació d’Oriola en el segle XIV. Barcelona, 1990, pág. 158. Doc. n. ${ }^{\circ}$ 43. Doc. n. ${ }^{\circ} 43$. pág. 374.

${ }^{27}$ El decisivo privilegio de 1296 que permitía la extracción de trigo de Orihuela, libre de impuestos y con destino a cualquier puerto de la Corona de Aragón, entró en clara contradicción con los privilegios que disfrutaba la ciudad de Valencia, como capital del reino de Valencia y que afectaron a la villa de Orihuela a partir de su incorporación al reino valentino. Pese a ello, las autoridades oriolanas defenderán con tesón la vigencia de este privilegio durante toda la Edad Media, en una tenaz pugna mantenida entre las autoridades locales de Orihuela y sus homónimos de Valencia. Sobre esta cuestión vid. RUBIO VELA, A., «Valencia y el control de la producción cerealista del reino en la Baja Edad Media. Orígenes y planteamientos de un conflicto», Aragón en la Edad Media. Demografía y Sociedad en la España bajomedieval. Seminario Historia Medieval, Zaragoza, 2003, págs. 38-40.

${ }^{28}$ Jaime I adoptó decisiones sobre la designación del principal magistrado municipal, antes de ocupar la ciudad de Valencia. BARRIO BARRIO, J.A, «El régimen municipal durante el reinado de Jaime I». Any Jaume I. Encuentros Académicos. El imaginario político del Rey. Alicante, 22-23 de noviembre de 2008. (En prensa). 
institucional ${ }^{29}$, con la recepción del derecho romano en primer lugar, a través sobre todo del reconocimiento a las ciudades de realengo de su condición de Universitas y la creación de las primeras oficialías municipales, para proceder a continuación al inició de la producción normativa, tanto con la concesión regía y la recepción de privilegios reales, por parte de cada centro urbano, como por la elaboración de un corpus legislativo con clara influencia en el código Justinianeo, que tendrá validez y vigencia para todo el reino de Valencia, a través de la producción legislativa emanada de las cortes del reino de Valencia, que desde el reinado de Jaime I y hasta las últimas cortes forales convocadas durante el reinado de Carlos II, permitirán el desarrollo de un código jurídico al servicio de los diferentes estamentos - nobleza, clero y ciudadanos - y los grupos étnico-religiosos - cristianos, judíos y musulmanes - que conformaban la población del reino de Valencia. Este nacimiento de las instituciones municipales iría parejo a la forja de unos símbolos específicos que configuraban una identidad propia en el conjunto del reino de Valencia. El programa de articulación política e institucional se complementará con la elaboración progresiva y gradual de un programa cívico, que «utilizando procedimientos y liturgias también sagradas, pretendía exhibir y proclamar el poder de las instituciones ciudadanas, crear un consenso político entre la población urbana, concitar una opinión pública favorable y al mismo tiempo afirmar la posición privilegiada de las oligarquías urbanas» ${ }^{30}$.

Este proceso plantea un doble desarrollo o modelo, por un lado, el interés de los conquistadores por trasladar a la nueva zona de dominio y gobierno, el sistema normativo de sus respectivas localidades de origen y por otro, el incentivo que pudo llegar a suscitarse entre la población local ya instalada en un centro urbano, por recibir y poder regirse bajo un determinado sistema jurídico-político.

Para el primer caso, podemos plantear dos ejemplos y modelos diferentes de análisis por orden cronológico. En primer lugar, el que se suscitó en la ciudad de Valencia, incluso antes de ser ocupada por Jaime I, a la hora de decidir la denominación que debía recibir el primer magistrado municipal de la localidad. Este primer nombramiento de un magistrado para la ciudad de Valencia es significativo, Jaime I utiliza una doble denominación en su designación, el término Curia

${ }^{29}$ En comparación con los procesos lentos y graduales que tuvieron lugar en las comunas del norte de Italia y en los municipios de la mayor parte de Europa, que iniciaron su articulación municipal entre los siglos XI y XII y la desarrollaron en los siglos siguientes, en el reino de Valencia el proceso fue más rápido e intensivo, dado que los modelos de articulación municipal se encontraban en estos momentos - 1238 - en una fase avanzada.

${ }^{30}$ NARBONA VÍZCAINO, R., «Ideología y representación cívica en la sociedad hispánica medieval», ID., Memorias de la ciudad. Ceremonias, creencias y costumbres en la historia de Valencia. Valencia, 2003, págs. 112-113. 
que refiere al origen catalán del oficio ${ }^{31}$ a la vez que el de Zalmedina que alude a un origen aragonés del cargo. Jaime I con ello pretendía dejar claro al grueso de sus pobladores, catalanes y aragoneses sus intenciones en la nominación de este cargo y agradar a ambos, sin mostrar una clara prelación o preferencia por ninguno de ellos. En junio de 1238 Jaime I volvió a designar a un nuevo Curia en la persona de Ferrán Garcés ${ }^{32}$ y dejando pospuesta la renovación anual del magistrado, quizás una prueba de que todavía no existía un grupo dirigente solido y solvente de la confianza del monarca. Delegando un año después la designación del titular entre la comunidad de prohombres de la localidad, que le debían presentar una terna de nombres, de la que el rey elegiría al nuevo Justicia y en su ausencia la elección la realizaría el Baile ${ }^{33}$. El término que finalmente se impuso, Justicia, suponía una denominación propia y específica para el primer magistrado municipal-real, designado para la ciudad de Valencia.

Otro ejemplo, tiene como escenario la ciudad de Cagliari. En el siglo XIV tras la conquista aragonesa de la isla ${ }^{34}$ se había conseguido destruir el dominio pisano y la nueva clase dirigente de origen catalán, decide eliminar de la forma más rápida posible el pasado identitario pisano, y sobre todo su herencia o huella jurídica-normativa. Para ello, se introdujo como código jurídico-normativo de referencia al llamado libro verde, que correspondía al nombre que recibía el

${ }^{31}$ El término Curia fue utilizado en las costums de Tortosa. Font Rius afirmaba el no carácter municipal del magistrado, utilizando el argumento de que era un cargo nombrado por el rey. FONT RIUS, J.M. ${ }^{a}$, Estudis sobre els drets i institucions locals en la Catalunya medieval. Col. lectanea de treballs del professor Dr. Josep M. ${ }^{a}$ Font i Rius amb motiu de la seva jubilació acadèmica. Barcelona, 1985, pág. 303. Cuando se promulga la costum de Tortosa, todavía no existe un régimen municipal en dicha ciudad, ya que no todavía no es considerada por el monarca como Universitas. Por tanto, el Curia en esta primera fase no puede tener un carácter municipal. En el caso valenciano consideramos al Curia como un magistrado de carácter mixto, real y municipal, ya que si bien detentaba la jurisdicción regía en primera instancia, era elegido y designado en el seno de la comunidad vecinal y sus competencias jurisdiccionales no se extendían más allá del ámbito del término de la ciudad. Es interesante apreciar que en las primeras designaciones que realizó Jaime I del nombramiento de Curia, en 1237 y en 1238, antes de la conquista de Valencia y antes de la concesión del régimen municipal a dicha ciudad, el Curia tenía el mismo carácter pre-municipal que el Curia Tortosino de la primera etapa.

32 El nombramiento se realizó en el Llibre del Repartiment el 25 de junio de 1238. A(rchivo) de la C(orona) de A(ragón). Cancillería, reg. 5, f. 27v. (1238, junio, 25). De la importancia del personaje dejo constancia Batllori en BATLLORI, M., «El cronista Bernat Desclot i la familia Escrivà», Storiografia e Storia. Studi in onore di Eugenio Duprè Theseider, Roma 1974, págs. 123-150.

33 NARBONA VIZCAÍNO, R., Valencia, municipio medieval. Poder político y luchas ciudadanas. 1239-1418. Valencia, 1995, págs. 26 y 68.

${ }^{34}$ Sobre la conquista de Cerdeña vid. ARRIBAS PALAU, A., La conquista de Cerdeña por Jaime II de Aragón. Barcelona, 1952. 
códice que recogía los privilegios de la ciudad de Barcelona y de otras ciudades catalanas.

Se llegaron a generar incluso modelos de libros de privilegios que eran adoptados en otras localidades, sin conocerse todavía, de forma adecuada, los mecanismos de difusión de estos códices. Así del libro verde de Barcelona, advertimos la difusión del mismo a localidades como Manresa ${ }^{35}$ o Cagliari ${ }^{36}$. El libro rojo fue el modelo de códice que se difundió por Sicilia. Estos códices recibían esta denominación por el color de las tapas. Dicho color se convertía, de esta forma, en una marca distintiva e identitaria del grupo dirigente urbano. Un caso muy interesante lo representa el libro verde de Cagliari. Tras la conquista catalanoaragonesa de la isla, el dominio pisano de la ciudad había sido destruido y era necesario suprimir la organización institucional que había establecido la república toscana y todos los elementos que se podían identificar con el pasado pisano e introducir elementos nuevos asociados al nuevo gobierno catalán. Uno de estos elementos identificativos con el gobierno catalán, fue el libro verde. Dado que la nueva colonia catalana instalada en Cagliari, había recibido el derecho a utilizar el derecho barcelonés, el libro verde debía servir para recoger por escrito los derechos y privilegios que recibirían de la Corona de Aragón. El libro verde de Cagliari es una copia del libro verde de Barcelona, que sirve como modelo y referencia para el de Cagliari.

El segundo modelo, corresponde al interés por recibir un texto normativo foráneo por parte de un centro urbano de la Corona de Castilla, la ciudad de Murcia, que negoció en secreto con Alfonso V su incorporación a la Corona de Aragón en $1448^{37}$.

Para facilitar la incorporación de la ciudad de Murcia a la Corona de Aragón, Alfonso V el Magnánimo, haciendo honor a su sobrenombre, prometía conceder a la ciudad de Murcia los fueros de Valencia como sí en todo momento hubieran pertenecido a la Corona de Aragón y que los «fueros le fuessen de tiempo de su prima poblacion atorgadas $\aleph^{38}$.

Esta última frase es elocuente, los ciudadanos de Murcia hubieran recibido de haberse incorporado a la Corona de Aragón, los fueros de Valencia con los mismos derechos que los ciudadanos de Valencia, cuya ciudad se había incorporado a la Corona de Aragón en 1238.

\footnotetext{
35 TORRAS, M. (Ed.), El llibre Verd de Manresa (1218-1902). Barcelona, 1996.

${ }^{36}$ DI TUCCI, R., Il libro Verde della Cittádi Cagliari. Cagliari, 1925.

${ }^{37}$ Para el relato pormenorizado y el análisis del intento de incorporar la ciudad de Murcia a la Corona de Aragón en 1448 vid. BARRIO BARRIO, J.A., CABEZUELO PLIEGO, J.V., «La defensa de los privilegios locales...

${ }^{38}$ A.C.A. reg. 2697, f. 3v. (1448, septiembre, 24).
} 
Los ejemplos de Valencia, Cagliari y Murcia, nos permiten ilustrar, bajo diferentes prismas y contextos, el interés de los grupos dirigentes de los centros urbanos incorporados a la Corona de Aragón o que se plantearon formar parte de la misma, por disponer de un sistema normativo propio, que se inserta en unas pautas comunes al de los espacios urbanos de las ciudades de la Corona de Aragón y en el contexto del proceso de la formación de las elites internacionales. A juicio de Iradiel, las elites internacionales fueron capaces de construir un espacio homogéneo para el ejercicio de la actividad económica y para la implantación de formas institucionales y jurídicas comunes de validez universal ${ }^{39}$. El papel de las principales ciudades de la Corona de Aragón fue fundamental para posibilitar la integración de las redes urbanas regionales de la Europa Mediterránea. Pero a la vez adquiere una singularidad propia en cada uno de los reinos o territorios, en que quedo articulada la confederación de reinos y condados denominada Corona de Aragón. En el Reino de Valencia, este complejo sistema de relaciones políticas, sociales y económicas entre los diferentes municipios, se configuraba sobre parámetros como el bien común general de la monarquía y del reino y el bien común y el servicio público de los vecinos hacia su propio municipio ${ }^{40}$. Directrices o criterios generales que en muchas ocasiones resultaban incompatibles. Sobre todo en lo referente a las líneas generales sobre las que se debían regir las estrategias generales del reino a través de los privilegios que concedía la monarquía, en temas claves como la organización de los sectores productivos, el mercado, la organización municipal, los sistemas electorales, etc ${ }^{41}$. En el norte de Francia, una de las zonas de Europa con mayor densidad urbana, los centros urbanos se encontraban cercanos en la distancia, tenían afinidades, similitudes y complicidades, pero cada una desarrollaba un microcosmos propio reflejado en un signos identitarios que la distinguían de sus vecinos ${ }^{42}$.

La siguiente fase en la construcción identitaria legislativa del reino de Valencia, fue el desarrollo normativo-legislativo que cada municipio pudo realizar, sobre su

39 IRADIEL, P., «Metrópolis y hombres de negocios (siglos XIV y XV)». Las sociedades urbanas en la España Medieval. XXIX Semana de Estudios Medievales, Estella, 15 a 19 de julio de 2002. Pamplona, 2003, págs. 277-310.

${ }^{40}$ BARRIO BARRIO, J.A., «La gestión pública, el bien común y la creación de redes clientelares en los municipios medievales del Reino de Valencia, ss. XIII-XV», Centros periféricos de poder na Europa do Sul, séculos XII-XVIII. Evora (en prensa).

${ }^{41}$ Como afirma Falcón Pérez, la organización municipal y la regulación de los sistemas electorales en los centros urbanos eran competencia exclusiva de la Corona, a través de las ordinaciones reales. FALCÓN PÉREZ, I., «Estatutos emanados del gobierno municipal de Zaragoza en el siglo XV», CAUCHIES, J-M. BOUSMAR, E., (Dir.), «faire bans, edictz et status»... pág. 368.

${ }^{42}$ ClAUZEL, D., ClAUZEL-DELANNOY, I., COULON, L., HAQUETTE, B., et alii, «L'activité législative dans les villes du nord de la France a la fin du Moyen Àge», CAUCHIES, J-M. BOUSMAR, E., (Dir.), "faire bans, edictz et status»: légiférer dans la villa médiévale. Bruxelles, 2001, pág. 296. 
capacidad para congregare y deliberare ${ }^{43}$, promulgando ordenanzas locales, que tenían aplicación legal sólo en el ámbito del alfoz o término de cada villa o ciudad del reino ${ }^{44}$.

Toda la documentación que se iba promulgando en el reino de Valencia, en especial los privilegios reales que recibía cada centro urbano, así como las ordenanzas que iba generando cada municipio, empezaron a ser compiladas, al menos desde el siglo XIV ${ }^{45}$, y fueron la base de la forja política de cada villa o ciudad y por extensión la base de la conformación de su identidad urbana y de su memoria histórica ${ }^{46}$, la de la ciudad, pero sobre todo, la de sus linajes. Para conseguirlo fue necesario disponer de unos mecanismos de compilación y archivo de la documentación ${ }^{47}$. Estos libros de privilegios,

${ }^{43}$ RIGAUDIERE, A., Gouverner la Ville au Moyen Age..., págs. 16-17.

${ }^{44}$ Un ejemplo de las ordenanzas municipales promulgadas en el reino de Valencia en Boixar, Xàtiva, Valencia, Gandia, VillaReal, Alzira Orihuela, Castellón de La Plana y El Maestrat, han sido publicadas en diferentes estudios y compilaciones documentales. MIRA, J.F, «Establiments de la vila del Boixar. Ensayo de análisis sociológico de las ordenanzas de una villa medieval valenciana», Estudios de Edad Media en la Corona de Aragón, vol. IX, Zaragoza, 1973, págs. 185-210. BOLUDA PERUCHO, A., Els manuals de Consells medievals de Xàtiva (1376-1380). Valencia, 1999. FURIO, A., Llibre d'establiments i ordenacions de la ciutat de València. Valencia, 2007. GARCIA-OLIVER, F., El Llibre d'Establiments de Gandia. Imatges i missatges en una vila medieval. Gandia, 1987. GIL VICENT, V., Ordenances municipals de Vila-Real (segles XIV-XVIII). Valencia, 2002. LAIRÓN, A., Las ordenanzas municipales de la villa de Alzira en los siglos XIV y XV. Alzira, 1986. LAIRÓN, A., Libre de diverses statuts e ordenacions fets per lo consell de la vila de Algezira Valencia, 2001. MAS I MIRALLES, A., Antonio Almúnia: Libre de todos los actes, letres, privilegis y altres qualsevol provisions del Consell d'Oriola. Valencia, 2008. OLASO CENDRA, V., El Manuel de Consells de Gandia a la fi del segle XV. Valencia, 2005. REVEST, L., Libre de Ordinacions de la vila de Castelló de la Plana. Castellón, 1957. GUINOT I RODRÍGUEZ, E., Establiments municipals del Maestrat, els Ports de Morella i Llucena (segles XIV-XVIII), Valencia, 2006.

${ }^{45}$ Dos centros urbanos de la importancia de Valencia y Orihuela, conservan actas municipales del siglo XIV.

${ }^{46}$ La memoria histórica, por otra parte, no deja de ser un atributo esencial de la identidad, asumiendo que ésta se forja a través de la «representación que de sí mismo hace y proporciona a la sociedad un grupo a partir de una selección interesada de su memoria histórica». HERNÁNDEZ FRANCO, J., «El pecado de los padres: construcción de la identidad conversa en Castilla a partir de los discursos sobre limpieza de sangre», Hispania, LXIV/2, 217 (2004), pág. 515.

${ }^{47}$ La villa real de Guardamar, perdió su condición de villa en 1366 y quedo convertida en «carrer» o aldea de la villa de Orihuela. Este hecho tuvo como una de sus consecuencias, la desaparición de su memoria histórica como villa, que quedo arrumbada e incorporada a la historia fundacional de la villa de Orihuela, al crear el mito histórico de Guardamar como aldea de Orihuela desde 1266. Con ello, la villa de Orihuela, eliminaba cien años de la historia de Guardamar y con tanto éxito que sólo en fechas recientes, ha sido recuperada la historia «independiente» de la villa de Guardamar. BARRIO BARRIO, J.A., «Guardamar en la Edad Media. De villa a aldea. La recuperación de la «memoria histórica» de un centro urbano portuario, aminorado por la historia» (en prensa). 
«tesoros» ${ }^{48}$ "aureum opus» ${ }^{49}$, eran considerados ya desde época de los normandos objetos preciosos. Los documentos, libros, reliquias de santos y joyas era usual que no se guardasen en espacios diferenciados, lo que implica que tenían una consideración similar ${ }^{50}$. Dentro de la documentación registrada y conservada en un archivo municipal, adquirían un valor singular, los fueros y privilegios fundacionales, que constituían, a juicio de Kammerer, el tesoro legislativo de la ciudad, conservado primero por los centros urbanos y después editado por archiveros o juristas, convirtiéndose en el capital simbólico de las ciudades, en el corazón de una memoria conservada y mostrada como las reliquias de una iglesia. Memoria urbana construida sobre el escrito, pero también sobre la tradición oral ${ }^{51}$. En palabras del director del Archivo de la Corona de Aragón, Carlos López Rodríguez «Fue sólo a principios del siglo XIV cuando confluyeron en la Corona de Aragón la custodia de documentos, gestión de la información y fe pública, los tres vectores que convirtieron los archivos bajomedievales y modernos de la Monarquía en eficaces instrumentos para el ejercicio del Poder ${ }^{52}$.

Por tanto, los grupos dirigentes de los centros urbanos del reino de Valencia, fueron forjando una identidad urbana similar y en un contexto histórico común al de las urbes sicilianas estudiadas por $\mathrm{Corrao}^{53}$, ya que su incorporación a la cristiandad Occidental y a la Corona de Aragón, se realizó también en el siglo XIII, sobre la base de unas instituciones y una legislación similar o el modelo analizado para Perpiñán, del que podemos destacar el papel desempeñado por el desarrollo de la idea de comunidad política y el sentimiento de ciudadanía asociada a la misma ${ }^{54}$.

48 RUBIO VELA, A., L'escrivania municipal de València als segles XIV y XV. Valencia, 1995, pág. 20.

49 ALANYA L., Aureum opus regalium privilegiorum civitatis et regni Valentie. Valencia, 1972. CABANES PECOURT, M. ${ }^{a}$ D. CABANES CATALA, M. ${ }^{a}$ L., Aureum Opus de Xativa. Zaragoza, 1996.

${ }^{50}$ CLANCHY, M.T., From Memory to Wrintten Record... pág. 155. England 1066-1307. Oxford (UK) \& Cambridge (USA), 2001.

${ }^{51}$ KAMMERER, O., «Practiques et normalisation législatives dans les villes du Sud-Ouest de l'empire (XIII -XVe siècles)», CAUCHIES, J-M. BOUSMAR, E., (Dir.), "faire bans, edictz et status»: légiférer dans la villa médiévale. Bruxelles, 2001, págs. 493 y 495.

52 LÓPEZ RODRÍGUEZ, C.L., «Orígenes del Archivo de la Corona de Aragón, (En tiempos, Archivo Real de Barcelona)», Hispania, 226 (mayo-agosto), págs. 413-454.

${ }^{53}$ CORRAO, P., «La difficile identità della città siciliane...», pág. 105.

${ }^{54}$ Vid. DAILEADER, Ph., De vrais citoyens. Violence, mémoire et identité dans la communauté médiévale de Perpignan. 1162-1397. Girona, 2004. 


\section{LOS POBLES NO ROMANGUESSEN SENS ALGUNA INSTRUCCION DE LA SANTA FE CATHOLICA. LA IDENTIDAD CÍVICA Y RELIGIOSA}

La incorporación del reino de Valencia a la cristiandad occidental en la primera mitad del siglo XIII y la entrada de Jaime I en la ciudad de Valencia en 1238, supuso la introducción desde las instituciones regias y eclesiásticas y de forma gradual de las instituciones, leyes, normas, fiestas, costumbres y religiosidad, que en el mundo urbano europeo estaban fraguando la identidad cívica medieval. En la consolidación posterior de este modelo urbano cristiano, será decisiva la aportación realizada desde las instituciones municipales.

La nueva sociedad surgida tras la conquista, se iba a regir bajo los parámetros de la sociedad feudal cristiana, imponiendo los conquistadores el modelo cultural que les era común, vigente en toda la cristiandad occidental, pero que resultaba ajeno a los musulmanes y judíos que vivían en las tierras valentinas, espacio que había estado bajo el dominio de la media luna durante más de cinco siglos, con la excepción del breve, efímero y estéril dominio del Cid en la ciudad del Turia. En una sociedad en la que los mozárabes posiblemente hacía tiempo que habían abandonado estas tierras - puede que tras la invasión Almohade o acompañando a Alfonso VI y a Doña Jimena en el desalojo cristiano de Valencia, tras la muerte del Cid. Como resalta Narbona Vizcaíno, no perduro ninguna tradición, ninguna memoria ni el recuerdo de ningún personaje venerable de la comunidad cristiana valenciana, con la excepción de San Vicente Mártir ${ }^{55}$, personaje cuyo martirio a principios del siglo IV es muy anterior a la conquista musulmana de la Península. Por tanto, cuando se produce la conquista cristiana de la ciudad de Valencia en 1238, no ha perdurado ninguna tradición, ni el recuerdo de personajes destacados de la comunidad cristiana valenciana posteriores al siglo VIII que pudieran ser venerados. Es una prueba más del escaso peso y eco que tuvo la comunidad mozárabe valenciana.

La cristianos que ocuparon el nuevo territorio conquistado, necesitaban de una profunda remodelación de las pautas religiosas, festivas, políticas, culturales y cívicas del espacio al que acababan de trasladarse, en su mayor parte, desde Aragón, Cataluña y Castilla. Además del papel desempeñado por el proceso político como refuerzo de la identidad y los valores colectivos, las pautas festivas cívica y religiosas, fueron el cemento que permitió mantener formas de cohesión, sociabilidad e identidad común a una población que venía de lugares dispares.

Para que los colonos cristianos instalados en el territorio, pudiesen vivir conforme a su identidad religiosa de base cristiana, las autoridades eclesiásticas

55 NARBONA VÍZCAINO, R., «Héroes, tumbas y santos. La conquista de las devociones de Valencia medieval», ID., Memorias de la ciudad... págs. 57-61. 
debían introducir el calendario religioso y festivo de origen cristiano, lo que fue realizado a través de la difusión de una red parroquial con una fuerte impronta urbana. Todo el proceso fue realizado ex-novo, ya que no existían tradiciones locales cristianas ni una red parroquial previa en las que sustentarse ${ }^{56}$. Se introdujeron las primeras fiestas religiosas en Valencia, atendiendo a los oficios del culto litúrgico repartido a lo largo del año, conforme a los principales acontecimientos de la vida de Cristo - Adviento, Navidad, Epifanía, la Cuaresma, la Pascua de Resurrección más la Ascensión y Pentecostés. Surge, de esta forma y en palabras de Narbona Vizcaíno, una nueva creación cultural: la identidad valenciana, con la configuración de elementos peculiares, como la forja de un panteón devocional específico del Reino de Valencia ${ }^{57}$.

Con el dominio cristiano de la mayor parte del territorio de la Península Ibérica en el siglo XIII, los grupos dirigentes urbanos van a incentivar la identidad de los centros urbanos con una mentalidad y religiosidad cristiana. Tras la derrota Almohade el proceso de conquista cristiana había llegado casi a su punto final, dado que la resistencia del pequeño núcleo islámico del reino Nazarí de Granada resultaba insignificante. La otrora colaboración entre los gobernantes cristianos y la elite judía en aras de una relación que podía resultar fructífera para los intereses de los reyes cristianos tenía sus días contados. Era el lento pero inexorable camino hacia la unificación religiosa y el liderazgo claro de la religiosidad cristiana. Se ponían los cimientos de una identidad cristiana hegemónica. La precaria tolerancia de los cristianos hacía los judíos fue substituida por un nacionalismo que hizo de la exclusividad religiosa uno de sus pilares definitorios ${ }^{58}$. A este proceso ayudó el impulso que se dio en los diferentes centros urbanos del reino, a las manifestaciones de la soberanía regia, con la celebración de diferentes fiestas cívicas y religiosas, que hicieron posible, en palabras de Narbona Vizcaíno, «el nacimiento de un hondo sentimiento nacional y afirmación patriótica» ${ }^{59}$.

En ciudades como Orihuela y Alicante, la desaparición de la mayor parte de la población musulmana tras la guerra de los dos Pedros y de la población judía en 1391 en la mayor parte de los centros urbanos del reino, facilitaron la reafirmación del dominio de la comunidad cristiana. Durante el siglo XV el modelo de moral y religiosidad cristiana se impone fuertemente bajo el impulso de las normativas legales que se irán aprobando gradualmente en los municipios

\footnotetext{
${ }^{56}$ Ibídem, pág. 68.

${ }^{57}$ NARBONA VÍZCAINO, R., «Tiempo de fiesta. La formación del calendario festivo valenciano», ID., Memorias de la ciudad... págs. 21 y 22.

${ }^{58}$ GITLITZ, D.M. Secreto y engaño. La religión de los criptojudios. Salamanca, 2003, pág. 21.

${ }^{59}$ NARBONA VÍZCAINO, R., «La fiesta cívica. Rito del poder real. Valencia, siglos XIV-XVI», ID., Memorias de la ciudad... pág. 69.
} 
valencianos, penalizando o reprimiendo los vestidos licenciosos, la blasfemia, el juego, la conducta sexual desordenada, las relaciones sexuales entre los individuos de las diferentes comunidades religiosas, etc. Es interesante también el apoyo prestado a las órdenes religiosas menores como la de los dominicos o los agustinos que se instalaron en el reino de Valencia y la difusión del culto mariano, con ejemplos como la invención de la leyenda del hallazgo de la virgen de Montserrate en 1306 en la villa de Orihuela ${ }^{60}$, cuyo culto se tuvo que iniciar, en realidad, en la ciudad de Orihuela, en la segunda mitad del siglo XV, coincidiendo en el tiempo, con la extraordinaria pujanza que tuvo el culto mariano en el reino de Valencia ${ }^{61}$

El mensaje cristianizador se difundía en las distintas clases sociales a través de la palabra y la fiesta litúrgica, caso de la procesión del Corpus ${ }^{62}$ y la escenificación de textos bíblicos y religiosos. Desde el siglo XIII la predicación fue impulsada en Europa por las autoridades religiosas y las clases dirigentes urbanas, que veían en el sermón la herramienta idónea para instruir a una sociedad analfabeta. Era frecuente la predicación en los centros urbanos del reino de Valencia de frailes de diferentes ordenes mendicantes, como queda recogido en las actas municipales de la villa de Orihuela en 1421.

${ }^{60}$ La leyenda difundida a principios del siglo XVI, era una narración que relataba como un pastor había encontrado en 1306, una virgen que había sido ocultada en los momentos previos de la invasión musulmana, en una zona extramuros de Orihuela y muy cercana a la parroquia de Sant Jaume. De forma inmediata se suscitó un debate entre los vecinos de la villa sobre cómo debía ser llamada la virgen. Los aragoneses propusieron Pilar, los castellanos Orito y los catalanes Montserrat. Tras un sorteo, la suerte fue favorable a los catalanes, por lo que desde ese día la virgen fue llamada de Montserrate. GISBERT Y BALLESTEROS, E., Historia de Orihuela. Tomo II. Orihuela, 1902, págs. 673-686. La historia es más compleja y nuestra primera hipótesis plantea una difusión del culto a la virgen de Montserrat en la segunda mitad del siglo XV y la propagación de la leyenda a principios del siglo XVI. La leyenda es una interesante reelaboración de la memoria histórica de Orihuela, ya que sitúa el hallazgo dos años después de la firma de la Sentencia arbitral de Torellas y la ubica en un culto mariano propio de Cataluña y perfectamente integrado en la religiosidad popular de la Corona de Aragón. En 1457 hemos conseguido documentar la presencia de un fraile de la «Virgen de Montserrat» que predicó en Orihuela. A.H.O. Contestador, n. ${ }^{\circ}$ 30. (1457, abril, 19). En 1483 está documentada la existencia de la cofradía de Nuestra Señora de Montserrate. GALIANO PÉREZ, A.L, Cofradías y otras asociaciones religiosas en Orihuela, en la Edad Moderna. Orihuela, 2005, pág. 56-57.

${ }^{61}$ NARBONA VÍZCAINO, R., «Tiempo de fiesta.La formación del calendario festivo valenciano», ID., Memorias de la ciudad... pág. 29.

${ }^{62}$ Caro Baroja consideraba que las fiestas de la Cruz y del Corpus, que se desarrollaban en las zonas donde había habido una mayor presencia musulmana, reflejan la intención subyacente de subrayar la adoración a símbolos básicos del cristianismo. MARTOZ NUÑEZ, E., SOUSA TRINDADE, V.M., (Coord.). La casa encantada. Estudios sobre cuentos, mitos y leyendas de España y Portugal. Mérida, 1997. 
«Item, fon ordenat que los justícia e jurats sien ab frare Antoni Pradell e que.al preguen que estiga en la dita vila tro a Pasqua florida per ço que sermonee en la dita vila. E que li donen cinch florins per a hun àbit. ${ }^{63}$.

Se irán definiendo y delimitando los márgenes entre los trabajos honestos y los deshonestos, entre los vestidos recatados y los licenciosos, entre las palabras licitas y las blasfemias, entre el tipo de vida adecuado y el indigno y la represión del juego y la prostitución.

Los marginados, vagabundos, prostitutas, delincuentes, leprosos, etc. son mal vistos por los vecinos y autoridades, que tratan de controlarlos dictando medidas reguladoras, o a través de la expulsión. Se establecen unas formas honestas y pautas cívicas de vivir y los ciudadanos que no se ajusten a estas normas sociales de conducta serán definidos como deshonestos.

También y como en otras ciudades europeas la máxima manifestación y expresión pública de la devoción cristiana cívica, fue concentrada en la procesión anual del Corpus Christi, organizada, estimulada y financiada por las autoridades locales. Surgida en el siglo XIII y que desde 1355 se celebraba en Valencia. Siguiendo su ejemplo se extendió su celebración durante el siglo XV en el resto de centros urbanos del reino y se convirtió en la fiesta de carácter cívico-religiosa, más importante del calendario festivo, movilizando prácticamente a todos los vecinos en su organización, celebración y participación, con una destacada representación de las autoridades municipales, que auspiciaban y financiaban la celebración de una fiesta, en la que se mezclaban los elementos religiosos con los profanos, con representación de entremeses o pequeñas piezas teatrales sobre la Eucaristía y los misterios bíblicos. La fiesta era celebrada «a glòria e llaor de nostre senyor Déu e honor e benefici de la dita ciutat» ${ }^{64}$.

Es una muestra más de que los principales elementos definidores de las oligarquías cristianas y su identificación plena con las manifestaciones de las elites europeas, introducidas en la primera mitad del siglo XIII se habían concretado y definido durante el siglo XIV y se desarrollaron y mejoraron en el Cuatrocientos. En los primeros años de la fiesta las autoridades se esforzaron por incentivar entre los vecinos, la devoción al Corpus y su participación activa en las celebraciones, estableciendo como debían ir vestidos correctamente, como engalanar sus casas, etc. Se aprobaron también disposiciones que obligaban a judíos y musulmanes a arrodillarse y adoptar una actitud solemne y devota ante el paso del Santísimo Sacramento. Fiesta en la que los oficiales y los prohombres de la ciudad desfilaban llevando en solemne procesión el palio que albergaba el cuerpo de Cristo.

\footnotetext{
${ }^{63}$ A.H.O. Contestador, n. ${ }^{\circ}$ 19, f. 53v. (1421, marzo. 8).

${ }^{64}$ HINOJOSA MONTALVO, J., Las tierras alicantinas en la Edad Media. Alicante, 1995.
} 
«Que.als dits ordenaments e capítols sien meses en memòria de scriptura». Modelos de...

«Majorment ara que deu ésser feta la festa de Corpus Crist en la dita vila. En la qual se fa solempne profesó. Elleven lo Corpus en aquella ab lo pali e penó, los qual lleven los oficials e los pus honrrats hòmens d'aquesta vila» ${ }^{65}$.

Desde la primera mitad del siglo XIII y durante el siglo XIV se produce en el reino de Valencia, por tanto, la construcción y consolidación de una Universitas cristiana ${ }^{66}$, de la que mudéjares y judíos fueron excluidos políticamente tras la conquista cristiana y la constitución de una sociedad política bajo dominio cristiano, en la que se desplegaron todos los elementos característicos de la celebración festiva, cívica y religiosa de las ciudades europeas. Durante el siglo XV se va a ir imponiendo de forma progresiva, sobre todo en el ámbito urbano, la religiosidad e identidad cristiana, dificultando de esta forma la vida de los judíos y mudéjares en las ciudades valencianas. Los dramáticos sucesos de 1391, son, en cierta medida, una consecuencia de la fuerte impronta que habían adquirido las pautas religiosas y cívicas cristianas, y un antecedente de lo que sucedió en Valencia en 1455 con el ataque que sufrió la moreria ${ }^{67}$, en 1481 con la introducción de la inquisición moderna en Valencia ${ }^{68}$, en 1492 con la expulsión de los judíos y en 1515-1516 con el bautizo forzoso de los mudéjares valencianos y entre 1478 y 1530 con la implacable persecución que sufrieron los judeoconversos valencianos ${ }^{69}$. Todas estas acciones, además de las inevitables y profundas motivaciones socio-económicas, confluyeron en un intenso reforzamiento de las identidad cívico-religiosa de base cristiana.

Se va a desarrollar, por tanto, una clara imbricación entre vida religiosa y sociedad civil, como ha advertido Narbona Vizcaíno con la coincidencia que se produce en la ciudad de Valencia, entre la celebración de Pentecostés y la renovación de los cuadros políticos municipales ${ }^{70}$.

Entre las festividades de carácter cívico que se celebraban en las principales ciudades del reino, cabe destacar sobre todo las fiestas asociadas a la conquista cristiana del territorio a los musulmanes, conformando un ciclo propio de «fies-

${ }^{65}$ A.H.O. Contestador, n. ${ }^{\circ}$ 16, f. 115r. (1417, junio, 3).

${ }^{66}$ Universitas o communitas forjada de forma notable sobre los valores del cristianismo y condicionada a partir de las pautas de la moral cristiana. DE MATTEIS, M.C., «Societas christiana e funzionalità ideologica della città in Italia..», pág. 17.

${ }^{67}$ RUZAFA GARCÍA, M.G., «Façem-se cristians los moros o muyren», Revista d'Historia Medieval, 1 (1990), págs. 87-110.

${ }^{68}$ NARBONA VIZCAÎNO, R., «La introducción de la Inquisición en las ciudades de Castilla y de la Corona de Aragón», LORENZO PINAR, FJ., (Coord.), Tolerancia y fundamentalismos en la Historia. XVI. Jornadas de Estudios Históricos. Salamanca, 2007, pág. 84

${ }^{69}$ HALICZER, S., Inquisición y sociedad en el reino de Valencia (1478-1834). Valencia, 1993, pág. 350. GARCÍA CÁRCEL, R., Orígenes de la Inquisición española. El tribunal de Valencia, 14781530. Barcelona, 1976.

70 NARBONA VízCAINO, R., «Tiempo de fiesta. La formación del calendario festivo valenciano», ID., Memorias de la ciudad... pág. 22. 
tas patrióticas ${ }^{71}$, como la celebración del 9 de octubre en Valencia iniciada cien años después de la conquista en 1338 en honor de San Dionisio ${ }^{72}$, o la fiesta en honor de San Jorge que se convirtió en el patrón de las milicias de Valencia o Alcoy, festejado con procesión propia desde $1341^{73}$ y la fiesta de las Santas Justa y Rufina en Orihuela, que conmemoraba desde principios del siglo XV la conquista cristiana de la ciudad a los musulmanes ${ }^{74}$. Esta exaltación del valor de los conquistadores, se había consolidado en la ideología del poder durante los siglos XI y XII ${ }^{75}$, ya que representaba una fuente de poder y termino convirtiéndose en la apoteosis de dicho poder, con la exaltación de cuantos ganaban batallas o reinos ${ }^{76}$. Al igual que sucedía en las ciudades italianas, en las que se forjo un patriotismo cívico y religioso, que relacionaba el municipio y la iglesia local, la ciudad y su santo patrón, la libertad política y la gracia espiritual ${ }^{77}$, en la ciudad de Valencia, tras la conquista de la ciudad, en la organización del calendario local de fiestas, jugó un papel destacado San Vicente Mártir, iniciando un santoral valenciano que fue enriquecido durante los siglos XIV y XV, adquiriendo su momento más destacado con la canonización de San Vicente Ferrer en 1455, primer santo propiamente valenciano ${ }^{78}$.

Finalmente hay que resaltar el papel que desempeño en Valencia, la organización y conmemoración por parte de las autoridades locales de la capital del reino, de las entradas reales ${ }^{79}$, que se desarrollaron en la capital del reino, denotando de forma clara el papel de capitalidad que ejercía sobre el resto de aldeas, villas y ciudades del reino. Como ha demostrado perfectamente Rubio Vela, la ciudad de Valencia ejerció una capitalidad efectiva y real sobre el resto del territorio del reino ${ }^{80}$. Las entradas reales realizadas en la Edad Media en la ciudad

71 Ibídem, pág. 25.

72 Para el estudio de la fiesta del 9 de octubre en la ciudad de Valencia vid. NARBONA VIZCAÍNO,R., El nou d'octubre: resenya històrica d'una festa valenciana (segles XIV-XX). Valencia, 1997.

${ }^{73}$ NARBONA VÍZCAINO, R., «Tiempo de fiesta. La formación del calendario festivo valenciano», ID., Memorias de la ciudad... pág. 25.

${ }^{74}$ Hemos localizado la primera noticia documental de la fiesta en el año 1404.

75 Posiblemente el tapiz de Bayeux del siglo XI, representé un claro antecedente del fuerte papel propagandístico e ideológico atribuido a la nobleza y a la realeza conquistadora.

76 BISSON, TH.N., La crisis del siglo XII. El poder, la nobleza y los orígenes de la gobernación europea. Barcelona, 2010, pág. 26.

77 MATTEIS, M.C., «Societas christiana e funzionalità ideologica della città in Italia...», pág. 22.

78 NARBONA VÍZCAINO, R., «Tiempo de fiesta. La formación del calendario festivo valenciano», ID., Memorias de la ciudad... págs. 22 y 27.

79 NARBONA VIZCAÍNO, R., «Las entradas reales en Valencia entre la Edd Media y la Edad Moderna. Siglos XIV-XVII», ID., Memorias de la ciudad... págs. 85-100.

${ }^{80}$ RUBIO VELA, A., «Valencia: la conciencia de capitalidad y su expresión retórica en la prosa municipal cuatrocentista», Anales de la Universidad de Alicante. Historia Medieval, 13 (20002002), págs. 6-63. 
de Valencia, han sido estudiadas de forma magistral por Narbona Vizcaíno, para quien «constituyen el momento privilegiado para la manifestación pública de la consciencia ciudadana e incluso de la afirmación nacional siguiendo fórmulas rituales de talente militarista, cívico o seudo religioso ${ }^{81}$.

\section{LA IDENTIDAD INSTITUCIONAL Y LA CONSTRUCCIÓN DE LA MEMORIA HISTÓRICA}

Narbona Vizcaíno ha destacado la simetría institucional en los niveles administrativos y políticos que rigieron el gobierno municipal de los principales centros urbanos de la Corona de Aragón ${ }^{82}$. El sistema municipal estaba formado por una asamblea representativa de la comunidad vecinal, el Consell, donde sus representantes eran elegidos por parroquias, estamentos y/o corporaciones, y un gobierno ejecutivo formado por un órgano colegiado de gobierno, los jurados. Como cabeza visible de la actuación judicial del rey en el municipio, se situaba el Justicia.

Una de las primeras actuaciones de Jaime I en la regulación de las instituciones urbanas en el reino de Valencia, fue la creación de la figura del Curia ${ }^{83}$, que era el magistrado que ejercía la justicia ordinaria en cada centro urbano. El oficial al frente de dicha oficina, el Justicia, representaba en cada localidad la autoridad delegada del rey y ejercía en su nombre la jurisdicción criminal y civil ordinaria.

La Curia era, por tanto, un tribunal de justicia que requería para el ejercicio de sus funciones de un magistrado al frente de la misma, de un edificio para poder celebrar los juicios y de una cárcel pública, donde poder encarcelar con todas las garantías procesales a los detenidos.

La primera disposición institucional de importancia que adoptó Jaime I tras la conquista, fue la regulación en 1239 de las características principales del tribunal de la Curia y la donación de un edificio como sede de dicho tribunal. Para ello Jaime I cedió unas casas situadas enfrente de la Catedral, evidenciando, de esta forma, la transcendencia política y jurídica que tenía el nuevo cargo. Además esta acción permitía acometer de inmediato la profunda transformación física que requería la ciudad de Valencia, una medina islámica que debía ser con-

${ }^{81}$ NARBONA VIZCAÍNO, R., «Las entradas reales en Valencia entre la Edd Media y la Edad Moderna. Siglos XIV-XVII», ID., Memorias de la ciudad...págs. 86-87.

${ }^{82}$ NARBONA VIZCAÍNO, R., «Algunas reflexiones sobre la participación vecinal en el gobierno de las ciudades de la Corona de Aragón (ss. XII-XV)», Res publica, 17 (007), pág. 113.

${ }^{83}$ En 1266 Jaime I procedió a una reorganización en profundidad del gobierno municipal de la ciudad de Valencia, estableciendo una nueva normativa electoral, dejando de forma definitiva el poder ejecutivo en manos de los jurados y poniendo al día la obsoleta institución de la Curia, que fue reemplazado por el Justicia. 
vertida en una urbe cristiana. La nueva urbanística de carácter cristiano, tendría en los palacios oficiales, el palacio Real, el palacio de la Curia o Justicia, el palacio del Gobernador, el palacio municipal, etc., la representación identitaria del poder del Rey y del nuevo municipio cristiano. Es en los programas de transformación urbanística y edilicia donde se suele desplegar una gran actividad cívica y regía, sobre todo en las ciudades que eran capitales de reinos y a las que acudía ocasionalmente el monarca, sobre todo con motivo de las visitas reales. En ciudades como Nápoles, sus ciudadanos, lamentaban las ausencias de los reyes como un perjuicio para la vitalidad urbana ${ }^{84}$. En el reino de Valencia, la ciudad más visitada por el rey era la ciudad de Valencia, la única que disponía de un palacio Real. Otras ciudades como Orihuela, veían en la figura del Gobernador General del territorio, la personificación del poder regio, por lo que ante ausencias dilatadas del máximo representante de la monarquía, las autoridades municipales solían reclamar al Gobernador que habitase de forma permanente en la ciudad, dado que ello redundaría en beneficio de la misma y de sus vecinos ${ }^{85}$. En la ciudad de Zaragoza, capital del reino de Aragón, sus habitantes consideraban que la ausencia del rey favorecía el desarrollo de tensiones y los actos violentos, mientras que la entradas reales eran las ceremonias que permitían a los ciudadanos de la capital del reino de Aragón, expresar su adhesión a la monarquía ${ }^{86}$.

La capitalidad de Valencia era ejercida de forma contundente y clara por sus autoridades locales, no sólo a través del papel que desempeñaban para la ciudad las entradas reales, sino además por el rol predominante ejercido por sus síndicos en las cortes del reino de Valencia, a la que enviaban más representantes que el resto de villas y ciudades del reino ${ }^{87}$, la instalación en la ciudad de las principales instituciones regnícolas, como la Generalitat, la Bailía, el Archivo Real de Valencia, o el principal edificio que representaba la autoridad del rey en el reino, el palacio Real.

Todo estos elementos reseñados representan y escenifican la capitalidad de la ciudad de Valencia, tanto en el plano político como sede de las principales instituciones regnícolas, como en la configuración de unos escenarios edilicios que irán perfilando toda una simbología en torno al papel de Valencia como capital

${ }^{84}$ KELLY, S., «Monarquía y ciudad. Consciencia cívica e identidad urbana en Nápoles antes de 1400», BOUCHERON, P., RUIZ GÓMEZ, F., (Coord.), Modelos culturales y normas sociales al final de la Edad Media, Cuenca, 2009, págs. 206-207.

${ }^{85}$ A.H.O. Contestador, n. ${ }^{\circ}$ 15, f. 262r. (1416, julio, 26 ).

${ }^{86}$ BARRAQUÉ, J-P., «La ville et la cour», e-Spania (En línea), 8 (diciembre 2009). En línea desde el 12 de enero de 2010. URL: http://e-spania.revues.org/index18806.html

${ }^{87}$ BARRIO BARRIO, J.A., «Los procuradores del brazo real en las cortes medievales del Reino de Valencia», Aragón en la Edad Media, XXI (2009), págs. 59-98. 
del reino, como la ciudad que mantenía una relación privilegiada con la realeza, en nombre de todos los valencianos.

Uno de los aspectos más destacados y resaltados de la actuación política de Jaime I, fue su decisión de crear una nueva entidad institucional tras la conquista de la ciudad de Valencia, el reino de Valencia, que fue constituido como un verdadero reino, al contrario que los de Murcia, Jaén o Sevilla, que en palabras de Furio eran designaciones virtuales y decorativas ${ }^{88}$. El nuevo reino era un espacio político, jurídico e institucional, autónomo y diferenciado del resto de entidades territoriales de la Corona de Aragón, y su nacimiento tuvo como principal consecuencia la creación y desarrollo de unas instituciones especificas del reino de Valencia y un corpus legislativo propio, cuyo primer cimiento fue la concesión a la ciudad de Valencia de la Costum de València en octubre de $1238^{89}$ o abril de $1239^{90}$, que era el texto legal que el monarca concedía a los repobladores de la ciudad del Turia. Este texto se fue extendiendo paulatina y progresivamente al resto de localidades del reino y se convirtió en el corpus legislativo del reino de Valencia, conocido como Els Furs. Con este modelo jurídico e institucional Jaime I acometió la construcción de un nuevo espacio político articulado sobre sus principales centros urbanos.

En el resto de villas valencianas de realengo, la recepción de la Curia y la costum o fueros de Valencia fue la línea seguida por Jaime I para el desarrollo de las instituciones municipales valencianas ${ }^{91}$. La concesión de la costum de Valencia fue una práctica habitual en la política de construcción política del reino de Valencia. En la década de 1240 se convirtió en el código que recibieron numerosos centros urbanos.

Con la instauración de los jurados en 1245 quedaba completada, aunque temporalmente, la base institucional del municipio Valenciano. Jaime I concedía en 1245 a la ciudad de Valencia, con carácter temporal, el privilegio de designar cuatro prohombres como jurados de la ciudad. La nueva organización administrativa y política del municipio valenciano cristalizará de forma definitiva en 1266, con la ratificación del privilegio de 1245 otorgándole carácter definitivo ${ }^{92}$ y con la creación de la figura del Justicia, que substituía a la magistratura judicial primitiva de la Curia.

\footnotetext{
${ }^{88}$ FURIÓ, A., Jaime I: entre la historia y la leyenda. Alzira, 2007, pág. 82.

${ }^{89}$ Fecha propuesta por VILLACAÑAS, J.L. Jaume I el conquistador. Madrid, 2003, pág. 289.

${ }^{90}$ Esta la fecha más temprana propuesta. BELENGUER, E., Jaime I y su reinado..., pág. 145. Como fecha más tardía Villacañanas plantea el 9 de marzo de 1240, día de la muerte de uno de los firmantes el obispo de Zaragoza. VILLACAÑAS, J.L. Jaume I el conquistador.., pág. 289.

${ }^{91}$ Algunas villas recibieron una carta puebla, como es el caso de Villareal que tuvo carta puebla a fuero de Aragón. BELENGUER, E., Jaime I y su reinado..., pág. 150.

92 NARBONA VIZCAÍNO, R., Valencia, municipio medieval... pág. 27.
} 
El control paulatino de los centros urbanos por la población cristiana y el desplazamiento de la mayor parte de los musulmanes al interior del reino o a localidades de señorío, facilitaba, como hemos visto, la configuración de una sociedad urbana bajo nuevos cauces culturales ${ }^{93}$, institucionales locales con carácter autónomo y con una legislación regnícola singular, dotando al conjunto de villas y ciudades del reino, de unas señas de identidad genéricas, que fueron luego perfiladas y desarrolladas en cada una de las urbes, verbigracia, con festejos específicos, leyendas patrióticas fundacionales peculiares, devociones marianas singulares, etc.

Observamos como todo el proceso de construcción de un nuevo reino y de creación de los nuevos aparatos administrativos y burocráticos residía en la novedad y en la originalidad. Jaime I adoptó elementos aislados de los territorios que había heredado de su padre, Cataluña y Aragón, pero no de forma mimética sino bajo una configuración más moderna en la aplicación y desarrollo del derecho romano. Así el cargo catalán de veguer no aparecerá en tierras valencianas, mientras que se utilizará el nombre aragonés de Justicia para el máximo magistrado municipal, pero en un cargo con un perfil y atribuciones muy diferenciados del Justicia aragonés.

En la base de la administración se situaba el Consell, un consistorio consultivo y deliberativo, que decidía sobre las principales cuestiones que afectaban al devenir cotidiano de las ciudades. La institución del Consell surgió a la vez que la del Curia y en principio como consejo consultivo del Justicia de Valencia ${ }^{94}$, pero con el paso del tiempo se convirtió en el órgano legislativo del municipio valenciano $0^{95}$, en un sistema regnícola de gobierno complejo, ya que los soberanos en su política regía basculaban sobre disposiciones legislativas variadas y en ocasiones contradictorias entre sí. El entramado legislativo del reino de Valencia se concretaba en los fueros, a continuación estaban los privilegios regios y en última instancia las disposiciones normativas de carácter municipal y con aplicación exclusiva en el ámbito local de la ciudad.

El Justicia era un oficial de carácter mixto, ya que por una parte tenía atribuciones de carácter regio, al desempeñar la justicia ordinaria del rey en el ámbito de su jurisdicción, la ciudad. A la vez era un oficial de carácter municipal, ya que era elegido en el seno de la comunidad vecinal y desempeñaba su oficio en

${ }^{93}$ NARBONA VÍZCAINO, R., «Ideología y representación cívica en la sociedad hispánica medieval», ID., Memorias de la ciudad... pág. 116.

${ }^{94}$ NARBONA VIZCAÍNO, R., Valencia, municipio medieval..., págs. 34 y ss.

${ }^{95}$ Podemos ver una parte de esta producción legislativa en algunas ediciones de textos realizadas sobre las normativas locales de municipios valencianos como Xàtiva, Valencia, Gandia, VillaReal, Alzira, Orihuela y Castellón de La Plana. Vid. Nota 42. 
el ámbito exclusivo de la ciudad, no teniendo ninguna competencia fuera del término o alfoz municipal.

Los justicias tenían jurisdicción en primera instancia sobre los delitos civiles y criminales que se cometiesen en la localidad donde ejercían la representación judicial. Desde el punto de vista terminológico hay que realizar una matización. En Cataluña las atribuciones que en Valencia tenía el justicia, como detentador de la jurisdicción real ordinaria, eran ejercidas por el baile o el veguer. En Aragón, en las Comunidades de aldeas de Daroca, el justicia también tenía la máxima jurisdicción, pero era nombrado directamente por el rey sin que el municipio participase en su designación. ${ }^{(96)}$ En Zaragoza correspondía al zalmedina ejercer la jurisdicción ordinaria para las causas civiles y criminales. ${ }^{(97)}$ En Mallorca e Ibiza, a juicio de Belenguer se procedió a la catalanidad jurídica de las islas y hubo tanta que, las máximas autoridades políticas fueron las que había en Cataluña ${ }^{98}$.

Además de estos cargos y oficios, base del organigrama municipal, existían en un segundo escalafón diversas magistraturas contables, sindicales y judiciales (almotacén, cequiero, etc.), el primero como responsable del mercado y el segundo con atribuciones sobre las cuestiones suscitadas en torno a las acequias y sistemas hidráulicos instalados en las huertas valencianas. Había también una gama variada de cargos municipales que podemos denominar de carácter servicial o subalterno, ya que desempeñaban funciones de gobierno asociadas al mandato de los cargos anteriormente mencionados.

Tras la elección de los cargos, la mayor parte de los nuevos oficiales, tenían que prestar de forma preceptiva el juramento correspondiente para poder ejercer la magistratura correspondiente. El acto del juramento era público y quedaba constancia notarial del mismo en las actas municipales, se extendió a otros ámbitos de la actividad urbana, como el juramento que tenían que prestar los inmigrantes para poder acceder a la condición de vecino. Éste acto denominado avecindamiento se realizaba en público, con testigos que avalaban la calidad del nuevo vecino. También realizaban el juramento correspondiente los embajadores de la ciudad antes de iniciar su actividad diplomática. Toda esta intensa actividad política del municipio, que incluía reuniones semanales del consistorio, tres elecciones municipales anuales, aprobación de ordenanzas, recepción de juramentos a los nuevos oficiales, nuevos vecinos, embajadores, etc., que era recogida de forma sistemática en las actas municipales, reforzaba a la vez

\footnotetext{
${ }^{96}$ CORRAL LAFUENTE, J.L. La comunidad de aldeas de Daroca en los siglos XIII y XIV: orígenes y proceso de consolidación. Zaragoza, 1987, págs. 90-92.

${ }^{97}$ FALCÓN PÉREZ, M. ${ }^{2}$ I. Organización municipal de Zaragoza en el siglo XV. Con notas acerca de los orígenes del régimen municipal de Zaragoza. Zaragoza, 1978, págs. 211-212.

${ }^{98}$ BELENGUER, E., Jaime I y su reinado..., pág. 110.
} 
la identidad de la civitas y la seguridad jurídica de todas las acciones políticas e institucionales acometidas por las autoridades, lo que además evitaba los riesgos de controversias y contestaciones ${ }^{99}$.

A lo largo de los siglos medievales, desde Jaime I a Fernando II, los monarcas fijaron los requisitos mínimos para desempeñar los cargos municipales en el antiguo reino de Valencia, reservando a una elite de prohombres el control de la res publica, del que estaban descartadas las mujeres que no tenían acceso a los oficios públicos, y las minorías religiosas de judíos y mudéjares ${ }^{100}$.

Conviene destacar que en un territorio de conquista, colonización y frontera como el reino de Valencia, la Corona mediante el expediente de conceder privilegios reales a una elite que podía garantizar el control del territorio conquistado, permitió la articulación de un aparato de poder que desde la conquista se basó en los concejos reconquistadores y repobladores dotados con un amplio alfoz, con un aparato burocrático-administrativo e identitario al servicio de las elites gobernantes, e importantes competencias legislativas, jurisdiccionales y hacendísticas, que el grupo político dirigente supo gestionar en beneficio propio. La relativa facilidad y rapidez en la ejecución de este vasto programa político-institucionalidentitario, se puede explicar por el contexto histórico y las circunstancias culturales existentes en el territorio en el momento de la conquista. De todo ello se benefició Jaime I para organizar con notable éxito la articulación política, jurídica e institucional del nuevo reino reciente creado. La conquista se produjo en el contexto de una Christianitas en expansión ${ }^{101}$. Cuando los cristianos llegan a las tierras que van a convertir en el reino de Valencia, el Islam y al-Andalus, se encontraban en un claro proceso de crisis política, militar y de articulación social de los territorios bajo su dominio. Crisis, por tanto, del propio sistema de dominio islámico, crisis fiscal, crisis del Estado, etc. Frente a ello, la cristiandad se mostraba pujante, emergente y agresiva.

Los cristianos feudales que llegaron a tierras valencianas se encontraban inflamados por un optimismo agresivo y expansionista. Era un mundo dinámico que recibió el impulso de los concejos, del derecho romano y de la escolástica, de la eficacia burocrática y de las instituciones monárquicas, del nacionalismo incipiente, de las lenguas vernáculas, de «modernas» técnicas militares y de nuevas

${ }^{99}$ CAUCHIES, J-M., «L'activité législative communale dans l'occident médiéval...», pág. 7.

${ }^{100}$ COLON, G., GARCIA, A., (Eds.), Furs de València... Llibre I Rúbrica III. Fur LXXXIII. Vol. I. pp. 217-218. AO, Priv. XLI Jaime I. 1251, noviembre, 28.

${ }^{101}$ Sobre el concepto de Christianitas y la expansión del occidente cristiano en el siglo XIII vid. BARTLETT, R., La formación de Europa. Conquista, colonización y cambio cultural, 950-1350. Valencia-Granada, 2003. 
técnicas comerciales ${ }^{102}$. Además de todo esto, cuando llegaron a tierras valencianas se encontraron con una avanzada y desarrollada tecnología hidráulica, que permitió a Jaime I beneficiarse de la tecnología del papel, introducida por los musulmanes en Europa a través de la Península Ibérica en el siglo XI en la ciudad de Xàtiva ${ }^{103}$.

De esta forma, Jaime I pudo aunar en beneficio de su política estatal y del desarrollo de los incipientes municipios que iba creando en el reino de Valencia, técnicas novedosas que se habían incorporado en fechas recientes al bagaje intelectual de la Corona de Aragón, como el ius commune, el ars dictandi y el ars notariae, que fueron ejecutadas por los técnicos del derecho - canonistas -, y los especialistas en la escritura - notarios -, que se pusieron al servicio de los agentes del poder en el territorio, la monarquía y el municipio y la posibilidad de disponer de un nuevo material escriturario, el papel, que permitía una producción elevada y barata del nuevo soporte documental y facilitaba la difusión del sistema cancilleresco en los centros urbanos y la redacción de una amplia masa documental, que registrada y compilada se custodiaba en los archivos locales.

El papel permitió superar en la organización institucional municipal, la fase de toma de acuerdos orales ${ }^{104}$ que se podían poner después por escrito ${ }^{105}$, ya que al menos desde la segunda mitad del siglo XIII o principios del siglo XIV, los municipios valencianos, van a registrar los acuerdos adoptados por el municipio, los estatutos o ordenanzas que formaban parte de la legislación en el ámbito local, así como las actas de las reuniones del consistorio, cartas, actos jurídicos, como el juramento de los oficiales, el juramento de los nuevos vecinos, concesión de poderes, y en la abundante relación epistolar mantenida por cada centro urbano, en numerosas ocasiones, se van a testimoniar los principales elementos que configuraban la identidad de cada urbe. Esta elaboración de registros docu-

${ }^{102}$ LE GOFF, J., SCHMITT, J.C., (Eds.), Diccionario razonado del Occidente medieval. Madrid, 2003, pág. 152.

${ }^{103}$ BURNS, R.I. El papel de Xàtiva. Xàtiva, 1999.

${ }^{104}$ Las primeras legislaciones municipales tenían un carácter oral. GODDING, P., «Les ordonnances des autorités urbaines au Moyen Âge...», pág. 188.

${ }^{105}$ En algunas pequeñas villas del norte de Francia, la fase de pasar los acuerdos orales a escrito se hizo tardiamente, a finales-principios del siglo XIV e incluso finales del siglo XV. CLAUZEL, D., CLAUZEL-DELANNOY, I., COULON, L., HAQUETTE, B., et alii, «L'activité législative dans les villes du nord de la France a la fin du Moyen Àge», CAUCHIES, J-M. BOUSMAR, E., (Dir.), "faire bans, edictz et status»: légiférer dans la villa médiévale. Bruxelles, 2001, pág. 307. Los privilegios más antiguos de las ciudades de Flandes fueron promulgados de forma oral, para ser confirmados por escrito posteriormente por los sucesivos condes. BLOCKMANS, W., «La normativa nelle cittá fiamminghe (secoli XI-XIII)», ROSSETI, G., (Ed.), Legislazione e prassi istituzionale nell Europa medievale, 67-77 (2002), pág. 70. Godding establece los origenes de la puesta en escrito de la legislación urbana en la primera mitad del siglo XIII. GODDING, P., «Les ordonnances des autorités urbaines au Moyen Âge ...», pág. 190. 
mentales, que se codifican con carácter anual, recoge sobre todo las ordenanzas municipales, base de la capacidad legislativa de la Universitas, la que da sentido a su doble capacidad de congregare et deliberare, dejando claro con la copia en los registros de todas las ordenanzas del municipio, de su capacidad exclusiva para adoptar estos acuerdos. El municipio se apoya, de esta forma, en la escritura para construir su poder ${ }^{106}$. Quedando vetado a los vecinos, corporaciones, cofradías, etc, adoptar este tipo de decisiones. Para hacerlo deberán presentar sus propuestas al municipio, que en caso afirmativo las adoptará, las pregonará y las copiará en los registros documentales pertinentes. Podemos comprobar cómo los capítulos y acuerdos de las principales corporaciones de oficios de la ciudad, quedaban registrados en los libros de actas de la misma ${ }^{107}$.

A juicio de Ammann-Doubliez ${ }^{108}$, la función del registro documental es convertirse en la memoria de la ciudad, ya que recoge los textos que produce (ordenanzas, acuerdos, sentencias), pero es asimismo la memoria de los hombres que sirvieron a la ciudad y los que la desirvieron ${ }^{109}$. Estos listados exhaustivos de jurados y consellers, van ser una característica común del discurso político de numerosos municipios de la Corona de Aragón. En los registros municipales se van a elaborar listas reiteradas y reiterativas de jurados, consellers, insaculados, etc $^{110}$. Se producía la elaboración de una memoria política que recoge las acciones honorables de los miembros de la oligarquía ${ }^{111}$. Pero también conocemos la elaboración de listados de vecinos desterrados de la ciudad de Orihuela ${ }^{112}$.

${ }^{106}$ AMMANN-DOUBLIEZ, CH., «Le grand livre des ordonnances de Fribourg / Suisse... pág. 29.

${ }^{107}$ Vid. BARRIO BARRIO, J.A., «Las reformas de la industria textil pañera en la ciudad de Orihuela en la primera mitad del siglo XV», Miscelánea Medieval Murciana, XXXI (2007), págs. 39-68.

${ }^{108}$ AMMANN-DOUBLIEZ, CH., «Le grand livre des ordonnances de Fribourg / Suisse... pág. 31.

${ }^{109}$ En el proceso que las autoridades municipales de la ciudad de Orihuela, siguieron contra el lider artesanal y popular, Joan Rodríguez, las autoridades decidieron dejar constancia escrita de todos los hechos para «memoria esdevenidor». Vid. BARRIO BARRIO, J.A., «El asociacionismo popular urbano en la segunda mitad del siglo XV. El procurador del pueblo de Orihuela en 1459-1460», Anuario de Estudios Medievales, 36/2 (2006), págs. 687-712.

${ }^{110}$ Así lo ha puesto de manifiesto Rafael Narbona en un reciente artículo, en él que se interroga sobre el interés que podían tener para los grupos urbanos «las extensas y minuciosas actas notariales y su interés por dejar constancia pormenorizada del nombre del miembros del Consell y de los cargos electos, aun desempeñando éstos funciones de carácter subsidiario». NARBONA VIZCAÎNO, R., «Algunas reflexiones sobre la participación vecinal... pág. 116.

${ }^{111}$ Sobre la memoria política vid. BORDONE, R., Uno stato d'animo. Memoria del tempo e comportamenti urbani nel mondo comunale italiano. Firenze, 2002, pág. 5.

${ }^{112}$ Giulano Milani ha analizado los registros de proscritos en Bolonia. Vid. MILANI, G., «Il Governo delle liste nel Comune di Bologna. Premesse e genesi di un libro di proscrizione duecentesco», Rivista Storica Italiana, 108 (1996), págs. 149-229. Id. «La memoria dei rumores. I disordini bolognesi del 1274 nel ricordo delle prime generazioni: note preliminare», DELLE DONNE, R., ZORZI, A., Le Storie e la memorie. In onore di Arnold Esch. Firenze, 2002, págs. 271-293. 
Es muy difícil establecer la cronología y la evolución de cada uno de los archivos municipales del reino de Valencia, debido a la destrucción de documentos que se han producido a lo largo de la Historia. Para numerosas localidades del reino de Valencia, la guerra de los dos Pedros, supuso la destrucción parcial o total de numerosos archivos locales, casos de Orihuela, Alicante y Gandía y posiblemente de otras localidades, de las que desconocemos absolutamente toda la historia de sus archivos locales. En el caso de los archivos locales de Alicante y Gandía, sufrieron daños en otros momentos convulsos de su Historia. En Gandía, durante las Germanías, fue destruida la mayor parte de los registros municipales. En Alicante, el ataque de una escuadra naval francesa en 1691, destruyo asimismo, la mayor parte de la documentación municipal.

Por tanto, es muy difícil establecer el momento de arranque de los registros documentales en los archivos municipales. En el Archivo Histórico de Orihuela se han conservado las actas municipales desde 1355. Esta fecha no es adecuada para indicar el inicio de los registros documentales, ya que las actas anteriores, fueros destruidas durante el ataque castellano a la villa durante la guerra de los dos Pedros. Creo que, además, en esta cuestión, debemos plantear una hipótesis. Estos archivos fueron destruidos intencionadamente. No fue una destrucción casual en el contexto del fragor bélico y los inevitables daños colaterales. Cada una de las destrucciones de estos archivos fue intencionada y el objetivo era claro, destruir la memoria histórica y la base político-institucional del rival. En Gandía, la serie ininterrumpida de registros se inicia en 1520, pero se han conservado unos pocos registros del periodo anterior, siendo el primero que se conserva en buen estado el correspondiente a los años 1484-1489 y 1497-1500 y que se ha editado en fechas recientes.

En el caso de ciudades como Barcelona, con una tradición jurídica y política en la órbita de la cristiandad occidental, anterior a los municipios valencianos, que cuenta además con un Archivo Histórico que ha conservado buena parte de su acervo documental, sabemos que la organización del municipio se produce a partir de un privilegio de 1249 , pero que las actas anteriores a 1300 , desaparecieron en un incendio, por lo que las series de las actas del Consell se inician en $1300^{113}$.

A la hora de establecer el origen de un archivo local, debemos establecer las funciones o causas que impelían a crearlo y organizarlo. El primer motivo, puede venir generado por la necesidad de archivar los privilegios reales y la documen-

\footnotetext{
${ }^{113}$ Para el estudio de las actas municipales de Barcelona vid. BATLLE I GALLART, C., FERRER I MALLOL, M.T., MAÑÉ I MAS, M.C., MUTGÉ I VIVES, J., RIERA I VIADER, S. ROVIRA I SOLÀ, M. El «llibre del Consell» de la ciutat de Barcelona. Segle XIV: Les elecciones municipals. Barcelona, 2007.
} 
tación regía recibida y el segundo y más importante, es por la necesidad de poner por escrito y archivar la producción normativa del propio municipio, sobre todo, dejar constancia escrita de las ordenanzas municipales, pilar jurídico de la vida normativa del municipio medieval.

En 1310 en una ordenanza del municipio de Valencia, se dejaba constancia que se había puesto por escrito, para evitar dudas, interpretaciones erróneas y para que no fallara la memoria en relación a dicha ordenanza.

«E com per oblidança d'òmens, los quals leugerament segons frèvol natura pot hom errar e no aver memòria de les coses, per ço manaren los dits jurats e prohòmens consellers que.als dits ordenaments e capitols sien meses en memòria de scriptura, a la qual cascú leugerament pot recórrer» ${ }^{114}$.

Este tipo de expresiones van a ser frecuentes en los registros documentales de las ciudades europeas. En la villa suiza de Friburgo, las menciones recogidas aluden a Remembrance que, Remembrance perpetual a savoir et a gardeir ${ }^{115}$.

En todo caso a la hora de plantear una hipótesis, tenemos que situar en la segunda mitad del siglo XIII, la fecha más temprana del origen de los archivos urbanos valencianos, siendo el siglo XIV, la época en que tuvo que producirse la eclosión de la mayor parte de ellos.

Desde esta perspectiva, Lehtonen, muestra el papel decisivo de la escritu$\mathrm{ra}^{116}$, que permitió la evolución de los poderes ideológicos, económicos y políticos y que tuvo una influencia indirecta sobre el poder militar. En este contexto ubica la reorganización del poder en Suecia, Finlandia y Estonia entre los siglos XII y XIV a partir de la conversión al cristianismo y la introducción de la escritura y el latín en estos espacios. Michael Mann también plantea que el poder ideológico permite determinar la interpretación que la comunidad hace de la realidad ${ }^{117}$. La conversión de los reinos nórdicos al cristianismo, es explicadaa, de esta forma, como la victoria de una nueva interpretación de la historia a través de los nuevos discursos de legitimación presentes en las crónicas dinás-

\footnotetext{
${ }^{114}$ FURIO, A., GARCIA-OLIVER, F., Llibre deestabliments i ordenacions de la ciutat de València. Valencia, 2007, pág. 23.

${ }^{115}$ AMMANN-DOUBLIEZ, CH., «Le grand livre des ordonnances de Fribourg / Suisse... pág. 35.

${ }^{116}$ Sobre el papel de la escritura en la evolución del conocimiento vid. OLSON, D.R., El mundo sobre el papel. El impacto de la escritura y de la lectura en la estructura del conocimiento. Barcelona, 1998. OLSON, D. TORRANCE, N. (Comps.), Cultura escrita y oralidad. Barcelona, 1998. PETRUCCI, A., Alfabetismo, escritura, sociedad. Barcelona, 1999.

${ }^{117}$ MANN, M., Las fuentes del poder social. Vol. I. Una historia del poder desde los comienzos hasta 1760 d.C. Madrid, 1991.

${ }^{118}$ LEHTONEN, T.M.S. «Préliminaires. Colonisation et culture écrite: les sources du pouvoir des élites au nord de la mer Baltique», LEHTONEN, T.M.S. MORNET, E., Les élites nordiques et L’Europe occidentale (XIIe-XVe siècle). París, 2007, pág. 15.
} 
ticas y otros documentos escritos ${ }^{119}$. Las conquistas del reino de Valencia y del reino de Murcia y la posterior reorganización del poder en los mismos, se hizo en un contexto similar, ya que fue decisiva, la cristianización del territorio y la introducción del lenguaje y las formas escriturarias latinas para la inmersión de territorios que habían formado parte de Dar-el-Islam desde el siglo VIII, en los referentes ideológicos de la cristiandad occidental.

Todos estos diferentes aspectos confluyen finalmente en la elaboración de una identidad colectiva, en la consolidación de una comunidad cristiana, sobre las bases de unos antepasados conquistadores que son glorificados, sobre la permanente existencia de un frontera que requiere de sucesivos esfuerzos bélicos por parte de los individuos que sustentan y reafirman esta comunidad.

Una de las imágenes más conocidas de la Orihuela medieval, es una miniatura conservada en uno de los libros de privilegios de la ciudad ${ }^{120}$, que nos muestra la ciudad amurallada y defendida por su castillo y asediada al otro lado del Segura por las tropas castellanas en el contexto de la guerra de los dos Pedros. El pendón real ondea en el castillo y en las torres de las murallas que están guarnecidas por la milicia urbana. A ambos lados las patronas fundadoras y protectoras de la Orihuela cristiana, Santa Justa y Santa Rufina. La simbología de la miniatura es propagandística y responde a un discurso de glorificación patriótica, como recogían las autoridades en numerosos testimonios, reiterando las gestas heroicas realizadas en defensa de la Corona de Aragón y la necesidad de ver recompensados estos improbos esfuerzos con privilegios y mercedes regías.

En el Cuatrocientos los miembros de las oligarquías urbanas son los descendientes de los antiguos combatientes de la frontera, que mantienen en su memoria las hazañas de sus antepasados y de ellos mismos contra los musulmanes granadinos y contra los castellanos, como se jactan de recordar en sus peticiones de privilegios a la Corona.

"Com los homens del loch d'Elch, qui son, segons que sabets, en frontera del dit regne, sien fort dampnificats per tales que los enemichs lus han fetes, els fan soven en lurs splets e bens, en tant que son en article de perdicio e despoblacio, ni han de que pusquen viure ni passar lur vida sino fort estretament».

Todo este programa de construcción de un aparato propagandístico para el ejercicio del poder en el ámbito local y que llevaba implícito la elaboración de un

\footnotetext{
${ }^{119}$ En la Edad Media la memoria se convirtió en un recurso imprescindible, tanto en la oralidad como sobre todo en las sociedades alfabetizadas que hacían un uso masivo de la escritura. CARRUTHERS, M.J. The Book of Memory. A Study of Memory in Medieval Culture. Cambridge, 1993.

${ }^{120}$ Archivo Histórico Nacional, Códices.L, 1368. Privilegia per Serenissimos Reges ciuitati Oriole concesa, f. 146r.
} 
discurso político que reafirmaba la identidad de la urbe cristiana, era construido y reafirmado por la elite dirigente, que tras la conquista cristiana fue elaborando una identidad que afirmaba y reiteraba su hegemonía, la necesidad de sus servicios y la gratitud que debía emanar hacia estos linajes que eran los detentadores de la memoria y la historia de la nueva comunidad cristiana y que estaba integrada plenamente en la Corona de Aragón.

\section{CONCLUSIONES}

La conquista y creación del Reino de Valencia en la primera mitad del siglo XIII, en un territorio que desde principios del siglo VIII se había integrado en el espacio de Dar al-Islam, implicaba para los conquistadores y los colonos cristianos del territorio, el deseo de convertir un espacio muy islamizado, en un reino cristiano similar a los que ya existían en la cristiandad occidental. La empresa iniciada por Jaime I se vio facilitada, por los avances que había experimentado la cristiandad occidental en las ultimas centurias. Los cristianos feudales que llegaron a tierras valencianas, conocían el papel dinamizador de las instituciones monárquicas, la institución municipal, el derecho romano, la eficacia burocrática, así como «modernas» técnicas militares y de nuevas técnicas comerciales.

De esta forma, Jaime I pudo aunar en beneficio de su política estatal y del desarrollo de los incipientes municipios que iba creando en el reino de Valencia, técnicas novedosas que se habían incorporado en fechas recientes al bagaje intelectual de la Corona de Aragón, como el ius commune, el ars dictandi y el ars notariae, que se pusieron al servicio de los agentes del poder en el territorio, la monarquía y el municipio y la posibilidad de disponer de un nuevo material escriturario, el papel, que permitía una producción elevada y barata del nuevo soporte documental y facilitaba la difusión del sistema cancilleresco en los centros urbanos y la redacción de una amplia masa documental, que registrada y compilada se custodiaba en los archivos locales.

Todos estos elementos que propiciaron la construcción del reino de Valencia, se vieron reforzados con la construcción de modelos de identidad urbana, sobre todo a través de una potente codificación normativa regia y municipal, el desarrollo de un intenso espíritu cívico-religioso, todo ello reforzado con la articulación político-institucional del reino cimentada con la elaboración de una memoria histórica al servicio de las elites dirigentes de las principales urbes. 